\title{
Two Songs by Muttuswami Dikshitar, Performed by T.M. Krishna and Eileen Shulman
}

TRANSLATOR'S NOTE, TEXTS, AND RECORDINGS

Muttuswami Dikshitar (1775-1835) is the most lyrical of the trinity of classical composers in the south Indian tradition of Carnatic music, which also includes his contemporaries Tyagaraja (1767-1847) and Shyama Shastri (1762-1827). All three, by the way, came from the same village of Tiruvarur. Two of his compositions are offered here, both of them in Sanskrit, like the bulk of his work. The first is part of a set of five kirtanas, or devotional songs, one for each of a set of five lingams of Shiva, associated respectively with the five elements of creation. Dikshitar loved composing sets of intricately intertextual kirtanas, each building upon themes hinted at in others of the same (or a parallel) series. In this case, the kirtana is directed at the invisible lingam of space in the temple of Chidambaram, where Lord Shiva performs his dance of joy; it is appropriately called "Luminous As Joy in His Dancing" (Ānanda-națana-prakāśam), after its first line. Those familiar with Carnatic music will recognize that it is in Kedaram raga, and that the performer is T.M. Krishna, arguably the finest of the male Carnatic virtuoso vocalists in our time. The second piece is a particularly haunting, melodic composition devoted to the goddess Kamakshi in Kanchipuram. It is entitled "Friend of the Goddesses of Life and Learning" (Śrīsarasvatī-hite), also after its first line. The raga is Māñji, and the performer is Eileen Shulman.

\footnotetext{
"LUMINOUS AS JOY IN HIS DANCING" BY MUTTUSWAMI DIKSHITAR
}

Sung to Shiva, the lord of Chidambaram, the lingam of empty space.

Raga: Kedaram

Beat: Miśrajāti ekatālam 
Rendition by T.M. Krishna. Streaming link provided by Charsur Digital Workstation.

Audio: https://www.charsur.com/song/detail/5394/1

Refrain:

I go to him, luminous as joy

in his dancing, Lord of the Chamber

that is awareness, lord of the goddess

who is his passion.

Pallavi (refrain):

ānanda-națana-prakāśam cit-sabheśam /

àśrayāmi śivakāmavallīśam

Second refrain:

Bright as ten million suns,

the infinite space in the heart

that gives both love and freedom,

who protects those who are in trouble,

who has shown his bent foot, soft as a lotus,

to the serpent Patanjali and the sage

with a tiger's foot,

luminous as joy in his dancing...

Anupallavi (second refrain):

bhānu-koṭi-sañkāśam bhukti-mukti-prada-daharâkāśam /

dina-jana-samrakșaṇa-caṇạ̣ divya-patañjali-vyāghrapāda-

darśita-kuñcitâbja-caraṇam

Verses (caranams):

Black Neck with the moon and the river

in his hair, who lives in Kedara and other temples

and in the ragas Shri and Kedaram,

god of ghouls, dressed in a tiger's skin,

dressed in the space of the mind,

the one sage who went missing

from the three thousand Brahmins,

god of everything, his heart

soft as butter, father of Guruguha, that is, of me

who sings this song,

the first of all, the one the Vedas know,

beyond passion, beyond even the raga,

who can be brought very close 
if you know anything about oneness, and who has many parts that take your breath away, parts that emerge from the singing and the playing and the happy game of the dance, luminous as joy in his dancing...

Caraṇams:

śîtânśu-gañgā-dharam nīlakaṇtha-dharam śrī-kedārâdi- kṣetrâdhāram bhūteśam śārdūla-carmâmbaram cid-ambaram

bhūsura-tri-sahasra-munīśvarạ̣ viśveśvaram nava-nìta-hṛdayam sadaya-guru-guha-tātam ädyam veda-vedyam

vìta-rāginam aprameyâdvaita-pratipādyam sañgìta-vādya-vinoda-tāṇ dava-jāta-bahutara-bheda-codyam.

FRIEND OF THE GODDESSES OF LIFE AND LEARNING BY MUTTUSWAMI DIKSHITAR

Sung to the goddess Kamakshi in Kanchipuram

Raga: Māñji

Beat: Ādi tālam (4 beat-lines)

Rendition by Eileen Shulman

Audio: https://doi.org/10.1525/luminos.114.2

Refrain:

Goddess, friend of the goddesses of life and learning, you are the thrill of awareness, fused into Shiva,

Pallavi:

śrī-sarasvatī-hite śive cid-ānande śiva-sahite

Second refrain:

Praised by Indra, king of the gods, and all the others, too, free from the dark fragrances of the past,

Anupallavi:

vāsavâdi-mahite vāsanâdi-rahite

Verses:

You who live in the shrine of a million desires, in Kanchi, your wrists decked with jeweled bangles, your heart softer than anything soft, the one hope of Guruguha who is me, who sing this song:

have mercy, care for me. 
Caraṇam:

-koți-nilaye kara-dhrta-mani-valaye

komalatara-hrdaye guruguhodaye mām ava sadaye

\author{
BEYOND PASSION, BEYOND EVEN THE RAGA
}

\title{
T.M. Krishna (Near Reader)
}

Every subsuming musical experience carries the sensitive listener, or rasika, beyond thresholds. Raga, pulse (laya), light, color, stories, history, religion, belief, and even identity become irrelevant. Much like tools, rules, and methods that provide access to learning, these paradigms are doors that grant us entry into life's inner sanctum. Once inside, the doors disappear. The sensitive audience includes everyone present, even the musician. The subsuming or drowning is collective yet intimate, together in solitude. Perceived dichotomies are left behind in a moment of wonderment. The musician is a mere catalyst, the song not his or hers.

In the first composition, "Luminous As Joy in His Dancing," Muttusvami Dikshitar speaks of Shiva in one compound word (vita-räginam) that has two meanings: he is "beyond passions, beyond even the raga." The composer may be referring to his own passion for the lord, but he knows that the lord is not trapped within his passions, just as when he speaks of being beyond ragas he implies that the lord is formless. In fact, he may be imagining the slow expansion of every raga particle much like the constantly expanding universe. When the smallest atoms become explicitly clear, in that moment of revelation, every raga comes together in unison. It is a unison, however, devoid of nomenclatures, structures, rules, forms: sound and melody become interchangeable, memory disappears, and living within the sound wave becomes a reality. At that moment, the raga underlying the composition, Kedaram, contains every sonic possibility.

Composed by a musical genius, "Luminous As Joy in His Dancing" is the first among five compositions dedicated to one of a set of five images of Shiva, each of which is thought of as the embodiment of one of the five primordial elements: earth, water, fire, wind, and space. Each of these is associated with a particular temple on the sacred grid of the Tamil country. The "Luminous" is dedicated to the "Space Lingam," that is, the invisible embodiment of Shiva in Chidambaram.

Any act of creativity is mystical. Every time we dip into its splendor, we discover multitudes of inner meanings as light enters through unnoticed crevices. This keeps happening at every encounter with the composition. Did the vāggeyakāra, that is, a single person as lyricist, composer, and arranger, know all this from the first moment when he conceived this art object? Is all this already laid out for us to stumble upon? We may never know the answer to these questions. But there is one thing we can be sure of: only in great art do we find both ourselves and the work anew every time. Even the very same line of melody that I have rendered a million times yields an unknown shade, the tiniest glide, or a 
subtle change in intonation every time I sing it. In these conversations between the composition, the composer, and myself, music occurs "beyond passion, beyond even the raga."

The "Luminous" opens with a soft glide from the niṣāda $(\mathrm{Ni})$ note in the lower register to the pancama $(\mathrm{Pa})$ in the same register. It is the enunciated vowel $\bar{a}$ - that holds this flow within, and by the time we reach the second part of the word, -nanda, on the middle register sadja $(S a)$, we are cajoled into änanda, or "joy." Muttusvami Dikshitar has Shiva oscillating between the temporal and the celestial. Shiva is performing his celestial dance, and his partner, Shivakamavalli, who is in unison with him, is also his witness. In the inner sanctum of the Chidambaram temple, Shiva, King of Dance (nataräja), is in ecstasy, and as he dances with abandon life happens. Very close to him, in that very same chamber, he exists as space. That root, primary form, is waiting to erupt and explode into resplendence. As space, he is known for being the "secret of Chidambaram" hidden in plain sight. The dancing god is the resulting extravagance in a state of aesthetic madness, while the invisible god is made approachable by the golden bilva leaves that adorn the space around him.

Space is real and unreal; it binds the real and the unreal to ensure that life is ever existent but never complete. Space is not empty, it is filled even when motionless, odorless, and tasteless. It is everything between and within the elements. It is unseen and unheard. It is the movement in the static and the stillness in movement that connects all of creation. The English word "ether" sometimes used to

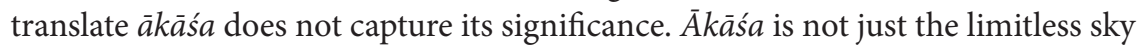
but also limitless time, both joined together.

In the secondary refrain (anupallavi) of this composition, Muttusvami Dikshitar shifts the tempo (laya) between Shiva as an indescribable, radiant, all-pervading ethereal nothingness, and as a physical and emotional being. This change in laya seems to demarcate the inner from the outer. The first line of the secondary refrain is:

\section{bhānu-koti-sankāśam bhukti-mukti-prada-daharâkāśam}

Immediately after this line, Muttusvami Dikshitar sketches for us a kind, caring, almost human Shiva, whose lotus-like bent foot is blessing "the serpent Patanjali and the sage / with a tiger's foot." This line is rendered in a faster tempo.

\section{dīna-jana-samraksaṇa-caṇaṃ divya-patañjali-vyāghrapāda-darśita-kuñcitâbja- caranam}

For some, this line can bring back memories of gazing through that little window provided for devotees at the Chidambaram temple. Peeping through those small openings we witness in awe the glittering golden bilva leaves hanging in the foreground against the backdrop of the dark rock face. $\bar{A} k \bar{a} s a^{a}$ envelops the whole space between the gold leaves and the black stones, even as ākāśa seems to move with 
the mild breeze that caresses the golden flowers when the temple priest moves the lamp to illuminate the space within. With the contrasting play of darkness and light, the stark and the ornamental come to life as the lamp moves. A few steps away the image of Shiva, King of Dance, is as physical as can be, poised on one foot with the other carefully angled in space, a statue in motion.

David Shulman and I engage with works of art from what could be seen as two opposite poles. Shulman extrapolates the spirit of life from every syllabic form, word, phrase, line, suggestion, and explanation. As Shulman sees with his mind's eye and hears with his mind's ear, meaning takes hold of his hand at the limits of logic and reason and leads him into unimaginable realms. In that space he finds new meanings and rare perspectives. I, in contrast, know that the spirit of life in music exists just in sound. That is, it exists in every sound, from the level of consonants, vowels, extensions, and aspirations, to the level of laya, tāla, rāga, and svara. As each folds into the other there is an explosive burst (sphuta) of identityless vitality, an all-pervading understanding of life. At no point do I devalue the pronunciation of every element or the articulation of lyrics, but I treat every syllabic expression as the primordial sound $(n \bar{a} d a)$, the sound that is the source of all sounds. I believe that the great composers, too, traveled the path of the semantic only to transcend into language's inborn domain-sound itself.

Still, it may be that we are not so different. One has only to read Shulman's translations or, for that matter, the writings of any great writer, to realize that semantic meaning is only a gateway, a point of entry. Once it is entered, meaning reveals its own being and allows an experience that is devoid of any selfish emotional benefit. In other words, meanings are abstracted from meaning itself, leading us to a state of dispassionate, intimate rapture. While I come to this state through sound, Shulman dives into it as a linguistic artist. I say artist because only an artist can free meaning from its prison.

When I decided to record the full set of Muttusvami Dikshitar's compositions dedicated to the five lingams, I first searched for older versions of "Luminous." These older versions raise seminal questions about oral and written traditions. Almost all of Carnatic music is learnt through oral/aural osmosis. Music books and notations can be aids in the process but rarely serve as learning resources in their own right. It is also very difficult to capture in written form the musical movements of ragas. That said, the practice of writing musical notation has been present in the India for over a millennium.

In recent Carnatic music history, Subbarama Dikshitar is probably the most important musician, musicologist, and scholar. In 1904 he published the Sangitasampradāya-pradarśini (SSP), a treatise that captures in theoretical and notational form the history of Carnatic music for the last three centuries. In over a thousand pages, the SSP gives modern Carnatic music an aesthetic anchor. It is also the first attempt to transmit this musical heritage using a descriptive notation system. Using innovative symbols Subbarama Dikshitar captured every musical 
-movement. It is from his book that I learned the "Luminous" and, in fact, all five compositions in this set.

Those who inherit oral traditions can feel an organic flow of thought that is intrinsically interpretive. This means that a composition never remains "as it actually is" in a positivist sense. Every master musician receives it only by adding curves, shifts, colors, and even melodic cadenzas. A composition is a living art object that never grows old. But the oral tradition is not perfect. Musicians are human beings and hence at times things are changed because the musician's own ego and the need for asserting his or her own identity overpowers musical appropriateness. And this may also lead to the loss of historical traces that are ingrained in the aesthetic architecture of the musical art object.

Subbarama Dikshitar's notations are based on the oral tradition he received. He put on paper what he heard and knew, and as a result the notations fix each composition within the context of his specific time and place; namely, mid-nineteenth-century Thanjavur, in the deep Tamil country. When we learn from Subbarama Dikshitar's notations, we travel back in time and rediscover lost melodies. This happened to me when I was learning the "Luminous." Sometimes the changes that have occurred may seem insignificant and minute. But when the composition unfolds and we pass through every one of those recovered accents, loops, turns, bends, and twists, we realize a seamlessness, something that seems to be erased in later versions. One such change is in the first line of the verse (caranam), where in the stretch gangä-dharam (Shiva with "the River [Ganga] / in his hair"), the second syllable gā is held on an elongated Madhyama (Ma) note, and the third syllable dha is held on an elongated Gändhara ( $G a)$ note. Today when the Kedaram raga is rendered, this musical phrase is almost never heard. But when I discovered it with the help of the notation in the SSP, it felt perfect, almost as if River Ganga had paused within Shiva's locks. Note also that in the very next line, the author, Muttusvami Dikshitar, incorporates the raga's name, Kedaram, in the phrase: śrī-kedārâdi-kṣetrâdhāram.

Niraval is a form of improvisation where the performer chooses a line from a composition and retains its syllabic and rhythmic structure while exploring other melodic contours possible in the raga (in this case Kedaram). In this composition the following caranam verse is usually chosen for niraval:

sañgìta-vādya-vinoda-tānḍ̂va-jāta-bahutara-bheda-codyam

But in this recording I have chosen a different line. I am not sure what made me choose this verse from the secondary refrain (bhukti-mukti-prada-daharâkāśam), but exploring a line that describes the subtle, ephemeral, and eternal being beyond the bounds of the line's original melodic framework did seem ideal.

With Muttusvami Dikshitar we can almost always find unexpected hints, connections, and interrelations in compositional construction, and this composition 
is no exception. For example, the number seven can signify the complete set of seven worlds, and the number fourteen, a multiple of seven, also has a special significance. In Hindu cosmology there is also a fuller set of fourteen worlds that make up the universe. It is said that the letters came into being when Shiva sounded his two-headed drum fourteen times. Thus it is indeed not surprising that Muttusvami Dikshitar's musical meditation on Shiva, "Luminous," is set to a rhythmic cycle of seven beats (the same is true of another composition, "You Took the Form of the King of Dancers in Chidambaram," Cidambara-națarāja-mūrtim).

Let me end my thoughts on this composition with Shiva's celestial dance that has been most poignantly re-created by Muttusvami Dikshitar in the very musical passage that concludes the composition. There is a conjunction between the words describing Shiva dancing, on the one hand, and the drum-like sound patternta-dhing-gi-na-tom-that is almost always used to conclude any purely abstract (nrtta) Bharatanatyam piece, on the other.

"Friend of the Goddesses of Life and Learning". Listening to Eileen Shulman sing the second composition, "Friend of the Goddesses of Life and Learning" (Śrī-sarasvatī-hite) my mind filled with cultural and political questions. Most high-culture stakeholders thrive on ownership and, being insiders, act as the gatekeepers of their tradition. In their minds, there is an innate sense of superiority, even condescension toward other cultures. When outsiders seek entry, they are vetted and forced to undergo a transformation. They must model themselves on the "owners" of the tradition. It is in this way that they can begin to be accepted by insiders.

Is Eileen Shulman an insider or an outsider? What do I hear when I listen to her: her own voice or the sound of my cultural pride. Look! Here is a Jewish musician singing a kirtana in praise of Goddess Sarasvati with so much beauty. Do I find myself thinking that she is quasi-Hindu, a convert of sorts in some way? Or that she is a Jewish Sarasvati?

But in her rendition Eileen Shulman does something entirely different than these thoughts of mine suggest. She takes the composition, imbibes its every nuance, and then fills it with her own self. Her performance is what it is, a tender musical outpouring that blurs every political, linguistic, racial, and cultural line that we routinely draw.

Eileen Shulman's unadulterated rendition forces me to reflect on myself as a performing musician. Musicians with a high level of professional proficiency are addicted to their own voice. This leads to a constant need to add, complicate, embellish, and even redraft the compositions of others. Increasing complexity brings us happiness. But as a result, the compositions lose their sheen and become too heavy as they are overlayered with musical ideas. Unable to withstand the weight of musical overindulgence, they fall apart. Eileen Shulman reminds me that being straightforward, simple, honest, and truthful is as essential in art as it 
is in life. In her rendition every graceful turn (gamaka) is clear, and that atypical, rare glide from the Madhyama $(\mathrm{Ma})$ note to the Shadja $(\mathrm{Sa})$ note as the secondary refrain connects to the primary refrain is rendered with utmost elegance.

Eileen Shulman's performance does justice to this second composition. Composed in Māñi raga, this Kirtana is a small delicate jewel. Even in this simple, descriptive offering to Goddess Sarasvati, Muttusvami Dikshitar manages to surprise. The composition begins with the word śri, which is sung in the Shadja $\mathrm{S} a$ ) note in the middle register, even though the intuitive musical reflex would be the note Rșabha (Ri). I have heard musicians struggle with this playful choice of Muttusvami Dikshitar. But it is also musically ideal for this particular raga. The musical phrase rendered in the first line ("friend of the goddesses") instantaneously brings the melodic identity of the raga to the fore.

Māñji has today become a rare raga. The reason for this marginalization can be largely attributed to the emergence of Bhairavi as a dominant raga. Not only did Bhairavi become a powerful raga in Carnatic music, it also changed in character. When this change happened, Bhairavi absorbed many melodic phrases that were typical of Māñji. As a result musicians have found it hard to render Māñji as an independent individual entity without crossing over into Bhairavi as it is performed today. Nevertheless, compositions like "Friend of the Goddesses" help understand and appreciate Mãñji on its own musical terms.

When Muttusvami Dikshitar asks Goddess Sarasvati to "care for me" (the last phrase from Shulman's translation of "Friend of the Goddesses"), he may be also asking for the same from all of us who render his compositions. It is not just his composition that is at stake here, but music itself. He is appealing to all of us to take good care of ragas, tâlas, and whole compositions. Every time I render his compositions, he seems to be whispering in my ear: "Allow yourself to be moved; let the music roam in freedom; respect the past but don't chain yourself to history; delve deep into musical creations and find yourself in every note and every word."

\section{READING IS AN ACT OF TRUST}

\section{Donald R. Davis, Jr. (Far Reader)}

The truth is, I don't much like classical Indian music. Even worse, I have no training in how to listen to or perform it. So, when Charles Hallisey, my friend and mentor, asked me to consider an essay in honor of David Shulman's model as a reader and grounded on two works of Muttusvami Dikshitar by two contemporary performers, I did so out of trust. What I write here is thus a double instance of the trust needed to prompt sensitive reading. Good reading entails friendship and esteem.

Words. In the composition that begins with the word "joy," themes of friendship, esteem, and trust structure the poet's relationship to the god Shiva. In this way, the poem itself tells us how to read it. The poet cries, "I go to him," or, I take refuge 
in the lord. In Sanskrit, it's just two words. Everything else builds on, extends, and specifies the word "lord." Taking refuge connotes dependence and yielding to the lord or master. The strong word "lord" suggests distance and difference, but in the characteristic manner of religious devotion, or bhakti, it is a distance that is meant to be bridged through intimacy. More subtly, "joy" exemplifies friendship in the stream of allusions to moments in the biography of Shiva or to his common descriptors. The poet recounts the moments of Shiva's mythological life as though he were there, as though he were an intimate part of the events themselves. Though addressed to Shiva, the many elaborations of who the lord is start to feel like an introduction, a report to a third party about a person the poet knows well. As in all of Dikshitar's work, he puts himself into the poem through his signature as Guruguha. This personalization, too, erodes the distance between the poet and Shiva in order for the words themselves to embody nearness and familiarity.

When Dikshitar put himself into the song, he also put me as the reader into the song. I am reading the poem both because a mentor who became a friend asked me to and because a genius whom we both revere as a master found in it something beautiful. The same distance that Guruguha feels in "taking refuge in the lord" is what I feel toward David Shulman. I've met him a couple of times. When I was a graduate student, I asked him a stupid question once at one of his lectures. Another time, he complimented my Malayalam-such scraps of praise are the stuff of deep memory for academics. But to me, he's mostly a "lord," a kind of distant master, with whom I have a relationship based on his published works. Those works, like Shiva's deeds, make me feel close to Shulman all the same. I think that's what this song is about, too.

The text calls Shiva "the kind father of Guruguha," which Shulman translates "the father of Guruguha, that is, of me" (emphasis mine). Dikshitar always signed his poems by referring to himself as Guruguha and Shulman's gloss makes that clear. But, the added clarification here refers less to Dikshitar, in my opinion, than to Shulman himself and, by extension, to me and to you, when we hear the song. "Guruguha, who is me" turns in trust to the lord who is "luminous as joy / in his dancing." I want to read this single compound as a string of nouns: "the joy that is dancing that is luminousness." In this reading, the lord is simultaneously joy, dance, and light. When Shiva dances, it means that he is moving in the world and "protects those who are in trouble." That protective movement is joy itself, not a dance of joy or one prompted by joy. If Shiva stops his dance, then we suffer because the world is not right. Joy ceases when the dance stops. Furthermore, light in our world-perhaps the poet means sunlight - is also Shiva's dance and thus we feel the sunlight to be joy and experience the light as dance, and we turn to theseto him-in dependence. The opening lines of the refrain, therefore, hit me as three nouns all referring to the same thing, to lord Shiva.

The opening phrase also modifies "the lord." In fact, every description in the poem refers simultaneously to the physical spaces and imagery in the 
Chidambaram temple and to widespread, often universal, theological epithets of Shiva. Each compound builds on the other and the doubled sense of each compound further complicates the referents and reference of the one lord. So, we are introduced to Shiva as joy, noting that joy here is also a name, the abbreviated name of the vigorous, cosmic dance of joy that is iconographically captured in the famous Nataraja form of Shiva in Chidambaram. But, we also take refuge in "the Lord of the Chamber / that is awareness," which refers to a particular shrine within the temple complex at Chidambaram. Subsequent descriptions layer on new elements or aspects of Shiva's identity. Among the other descriptions or epithets of Shiva, the "infinite space in the heart / that gives both love and freedom" points especially to the "lingam of space" in Chidambaram, one of five lingams, a standard image of Shiva, in the temple that correspond to each of the cardinal directions plus the invisible lingam of space itself. The idea that Shiva is this subtle "infinite space" (a reference to Chāndogya Upanișad) might also be rendered as the fine spaces in between all things. Shiva exists in all things as the "lord of existent beings" who is also the "god of ghouls" (in Shulman's translation of the same phrase) by permeating the fine spaces. Through such double referents, the words thus teach us that Shiva lives next door to us in Chidambaram and yet he is the god of everything.

One final description seems to draw on a theological principle linking this song of Dikshitar to the other song, "Friend of the Goddesses," which I will consider shortly. When the lord is described as "the one who can be brought very close if you know anything about oneness," the language draws upon the enigmas of the Upanishads (especially Chāndogya Upanișad 6.1). Later poets searched for ways to communicate that God or Brahman is one, but describable in many ways. In Dikshitar's works, this search manifests poetically as long strings of different descriptions marked with the same grammatical ending. The one-in-many structure of language, therefore, mirrors the ontological structure of the universe. Just as many nouns and adjectives describe the one in different ways, so also does the plurality of our ordinary lives describe or rest upon the one true cause of the phenomenal world. The words are the body of the poem just as the material world is the body of God.

The proliferation of distinct descriptions of God, therefore, is essential and basic for a bhakti-centered poetics in favor of any deity. To learn the true oneness of God, there is no better way than to see how all names, epithets, and descriptions refer back to the singular lord. The shorter second poem, "Friend of the Goddesses," also consists of a long series of compounds, all marked with the repetitive grammatical ending used to address or call people, in this case Goddess Kamakshi (or Kamakoti) of the great temple and monastery at Kanchipuram, two hundred kilometers north of Chidambaram. Then, right near the end, the command "care for me" makes a simple request of the goddess using an archaic verb. To a Sanskrit ear, this plea might sound like "bless me and keep me" would in English—old, but poignant. In Shulman's elegant rendering: 


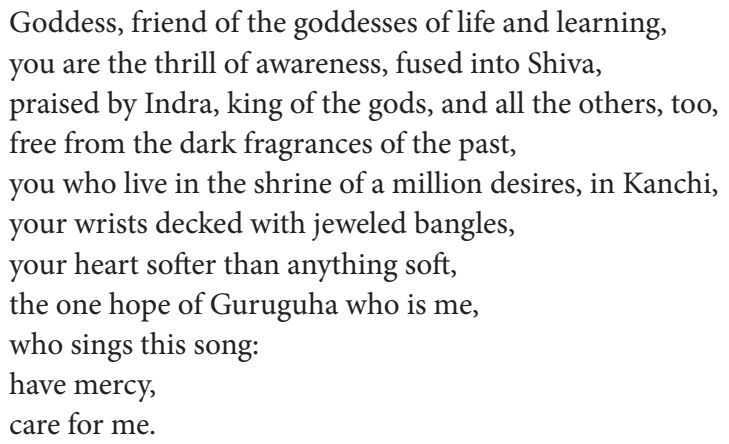

The "shrine of a million desires" locates this song in Kanchipuram and the special shrine for this goddess. Dikshitar's self-reference as Guruguha identifies the supplicant as "me," even before the word "me" appears. Apart from the beautiful lyricism in the nearly homophonous secondary refrain "vāsavādimahite vāsanädirahite" and the syllabic rhythm of "[koma]la-ta-ra-hrdaye gu-ru-gu-hodaye," the thing that strikes me about the structure of the poem as a written text is the stringing together of simple or compound descriptions in the same grammatical case that we saw in the first song. In fact, both poems exemplify a very common pattern found in the structure of bhakti poems written in a theological context of Vedanta. Long series of epithets in the same grammatical inflection cluster around the singular figure of devotion. That grammatical unity is taken as reflecting an ontological oneness behind reality. Language, specifically nouns and adjectives describing the deity, serves as the bridge to the experience of the deity. The best way to experience God, therefore, is to spin out name after name and description after description until all diversity circles back to the one.

Sounds. The words of these two songs by Muttusvami Dikshitar contain both beauty and idea, but we know them today not because of their content but because of their sound. What we cannot see in the lyrics by themselves is how they are heard in actual performance; that is, how the words become sounds. In this section, I offer a "reading" of performances of the two songs. I suppose the ear is the organ of reading in this case, not the eye, though it is important to distinguish what the eye can do from what from the ear can do. The first impact of sound concerns the way in which an oral recitation of the poem would sound. Do the words themselves have a beauty and a sense as sounds apart from their meaning? Robert Frost spoke to this poetic power:

The ear is the only true writer and the only true reader. I have known people who could read without hearing the sentence sounds and they were the fastest readers. Eye readers we call them. They can get the meaning by glances. But they are bad readers because they miss the best part of what a good writer puts into his work. Remember that the sentence sound often says more than the words. . . To judge a 
poem or piece of prose you go the same way to work-apply the one test-greatest test. You listen for the sentence sounds. ${ }^{1}$

Frost speaks here of sounds of the first-order variety, the sound-shapes of the words themselves before they become part of a song. When the words become lyrics and sounds, the arrangement introduces repeats and codas and the singer explores the possibilities of the sounds within the tune and rhythm. Sure, the sound-shapes matter, but, in my opinion, this second-order sound quality is the locus of primary meaning for a song. People like the tune, the beat, or the vibe before they study the lyrics.

Our first performance of a Dikshitar song comes from T.M. Krishna. I have listened to his rendition of "Luminous As Joy" many times, and let's just say he can make someone who has not previously connected (much) with Indian vocal music find something to love. The effect of his voice is alluring and seductive. There's great control and incredibly difficult movement in his voice. That control makes it professional and full of calculated risks, but not emotional abandon. He knows he will get to the notes in the way that he wants. He has a prepared idea of how the song should go and he can execute that idea beautifully, but you can hear the planning, even if the precise execution might vary from one performance to another. And so should it be. He treats Dikshitar's song with as much respect as the poet himself did and puts his professional skill to work accordingly. I do not mean to suggest that T.M. Krishna lacks sincere emotion in his singing here, but rather that his performance properly channels the emotional qualities of the song through a virtuoso's voice. An expert's voice provides structure and intelligibility to the raw emotions of the song.

Krishna opens the refrain in the standard way for male Indian vocalists: a head voice that will reach high tenor notes later begins in a tenor's version of baritone. It is a note that sounds lower than it is (somewhere around D below middle C). The middle range of the opening is a soft point of entry to the high pitches to come in the refrain, secondary refrain, and verses. The ensemble consists of voice, harmonium, tabla, and violin. The congruence of voice and violin in the melody is incredible, especially considering the tonal flourishes that both agree upon. The percussion both breaks up and emphasizes this congruence, moving things forward here and underlining things there. The harmonium, as always, adds an ambience, a constant of sound that unifies the instruments and voice but also seems to bend with them.

The performance repeats the refrain and parts of the refrain several times, then does the same for the secondary refrain. Each verse receives thorough treatment too, though not with the same level of repetition. The first half of the performance offers what seems to be a kind of standard version of the poem in song: multiple refrains and secondary refrains with limited verses. After finishing the second verse, however, Krishna sings the tune with the syllabic sounds of the Indian scale, 
not the words of the poem. Here the rhythm and pitch matter, not the semantic content of the words. In fact, the drive of the song at this point seems to be exactly the diminution of linguistic meaning in favor of sound. The meaning of the words is respected as such for half of the song, after which the performance begins to tear the words apart and to use them as sounds.

Twelve minutes in, Krishna sings "space" (ākāśa) and then "infinite space in the heart" (daharākāśa) in repeat. Just when the repetition starts to feel repetitious, he works backward in the compound, adding "gives both love and freedom." It would sound in English like: "space, that space, that infinite space, that infinite space in the heart that gives both love and freedom." The violin sings the same, building and rebuilding the compound in strings. Krishna then builds the compound again from the end to the beginning, breaking the construction by building the compound with syllables of pitch "ma ga ma ma pa sa ni ni ta..." The embellishments of "space" yield then to repeats and variations on "love and freedom" interspersed with further syllabic flourishes. The song ends on the refrain and the words "I go to him ... lord of the goddess / who is his passion."

Reading the words of the poem would suggest that the keyword or the main descriptor of Shiva is "lord," since it occurs five times in a short song. Listening to the sounds of the song, however, we realize that the most important word is "space" and the most important phrase is "the infinite space in the heart / that gives both love and freedom." Religious devotion demands specificity and location. God cannot be some distant abstraction, an imaginary reality. Rather, God should have presence and form in a space that we know, can see, and can visit. The song, therefore, is an ode to the lingam of "space" within the "chamber that is awareness" (citsabhā) of the Chidambaram temple. Such specificity does not deny the universality of Shiva or his power as lord. Rather, it crystallizes his presence in a particular place, thus making him accessible in the tangible, material form of the Chidambaram temple. The lovely paradox in this case is that empty, invisible "space" is not physical at all and yet the song and the temple give it a physical reality. When Krishna utters "space" his voice fleetingly embodies the lingam of space at Chidambaram. As devotion makes the universal local, the voice localizes the deity's presence in sound. The devotee and the singer have to initiate the process, however. Each makes the presence of Shiva real for the duration of their worship, attention, and song. For this reason, I, like all others, must take refuge in, call out to, and choose the deity anew in each moment.

The first recording of "Friend of the Goddesses," by Eileen Shulman, had a remarkable and unexpected effect on me. This voice, this singer, has sung this song many times before. Perhaps it sang once for the benefit of others, but now it is self-confidant and self-contained, though not selfish. The song is an offering of the singer to the goddess. It is between the two of them. The voice sings through a memory of a past singing and thus feels distant from the moment of 
the performance. I feel the memory as much as the song and that is what haunts me: the singing pushes me to the memory and not to the song. The sound asks me to imagine the memory in my mind and to ignore the song in my ears.

To discover more about the song, I also turned to a recording of "Friend" by R.K. Shriramkumar, a violin virtuoso. It is a performance at the Boyer College of Music and Dance at Temple University, Philadelphia, in which Shriramkumar teaches the song to a full auditorium. Since it is not a solo performance but more like a master class, the emphasis on sound is even more pronounced since Shriramkumar will linger on a single syllable and repeat flourishes that are just the vowel sounds: "hite . . ite . . e." As he patiently moves the audience through the poem, the units of interest and repetition shift and change. He sings the entire opening address, "śri sarasvatìhite," then just "śr $r$ " with a dip in pitch. After the audience tries it, we hear "sarasvatìhite" which they don't quite get. So, then "sa ... sa-ra . . sarasvati . . hite . . hite . . hite." The ornament on " $t \vec{\imath}$ " (doubled pulse on the same pitch) is tricky for most, hence the repetition. But now it's good enough. Good news for the audience: "śive" is the same notes and ornament as "hite." Change the consonants and repeat. We're highish in the vocal register now, so "cidānande" has to give us some relief. It moves down the scale from a slight rubato on " $\bar{a}$ " to a similar ornament on the next " $e$ " at the lower pitch and falling off. The final "sivasahite" of the refrain loops around the same pitch in quick rhythm. The surprise comes when the initial "śr $r$ " is quickly appended to the end of the refrain as a new beginning, a repetition. There's always a slight pause after "s $r \vec{r}$ " whether the sounds stops or not. The end becomes the beginning in fact as the refrain actually ends on "sarasvatihite" with an elongated "e."

Though this version of Dikshitar's poem is a casual teaching of how to sing the song, the place where Shriramkumar wants to arrive throughout is the union of two voices, human and violin. The performance involves no translation of the words. When the audience gets the gist of a section, he then plays the song on his violin along with them, guiding and reminding them with its sharp sound. Shriramkumar's instrument is his violin, not his voice. His voice is pleasant but not as powerful or versatile as Krishna's. In this context, the quality of his voice is not at issue, however, because it is a lesson. Teaching the audience the words and tune of the song is an excuse to get them to experience something of the power of the union between voice and violin. That union is only sustained for short moments of the lesson overall, but it appears vicariously to have its desired effect. The audience nervously giggles here and there when their voices come together nicely or when the violin carries their voices through the end of a phrase. The taste of such unity seems to be the purpose of the lesson.

As I try to make sense of these two very different performances of Dikshitar's "Friend," to read them as sounds, the image that comes to mind is once again from the Chändogya Upanișad (6.8.2): "It is like this. Take a bird that is tied with string. 